\title{
Przemówienie prezydenta Republiki Austrii Alexandra Van der Bellena z okazji obchodów w byłym obozie koncentracyjnym Gusen ${ }^{1}$
}

W uroczystościach upamiętniających 72. rocznicę wyzwolenia byłego niemieckiego obozu koncentracyjnego KL Gusen, które odbyły się 6 maja 2017 roku przy Memoriale KL Gusen, uczestniczył po raz pierwszy w historii prezydent Republiki Austrii. Jeszcze nigdy tak wysoki rangą przedstawiciel władz Austrii nie brał udziału w oficjalnych obchodach w tym miejscu.

6 maja 2017

Szanowni Państwo!

Moje pozdrowienie kieruję w sposób szczególny do obecnych tu osób, które przeżyły prześladowania narodowosocjalistyczne, które przeżyły KL Gusen, i do ich potomków.

Jestem pod wielkim wrażeniem, kiedy ludzie, którym wyrządzono tak wiele krzywd, wracają do miejsc prześladowań, tortur i mordów.

Jest to upamiętnienie towarzyszy losu, zobowiązanie i przestroga dla nas wszystkich.

Witam serdecznie również tych wszystkich, którzy dzisiaj angażują się w pamięć, upamiętnianie i organizację [wydarzeń] w Gusen.

Uważam, że to bardzo ważne, iż zostały tu zrealizowane liczne projekty, nawiązujące do inicjatyw upamiętnienia podejmowanych przez byłych więźniów i podtrzymujące pamięć o niewyobrażalnym okrucieństwie, które się tu wydarzyło.

\footnotetext{
1 Treść przemówienia pochodzi ze strony internetowej Kancelarii Prezydenta Austrii: http:// www.bundespraesident.at/newsdetail/artikel/die-zeiten-sind-nicht-vergleichbar-mit-den-30erund-40er-jahren-vergleichbar-ist-aber-die-gefahr-dass-wir-die-sensibilitaet-die-empathie-fuer-unseren-nachbarn-arbeitskollegen-oder-hilfesuchende-verlieren (dostęp: 14 marca 2018).
} 
W centrum dla zwiedzających, wybudowanym w 2004 roku, znajduje się imponująca stała ekspozycja poświęcona historii KL Gusen. Ostatnio otwarto również dla zwiedzających wystawę plenerową dotyczącą historii kompleksu sztolni Bergkristall.

Uzupełnieniem wystaw są inne różnorodne oferty.

Te projekty są finansowane zarówno przez Republikę Austrii, jak i inicjatywy regionalne i partnerów międzynarodowych - przy udziale społeczeństwa obywatelskiego.

Dziś stoimy w tym miejscu 72 lata i jeden dzień po wyzwoleniu tego obozu. Ponad 70 tys. ludzi z całej Europy zostało wyrwanych z kręgu najbliższych, ze swojego życia, i musiało tu w Gusen doświadczyć na własnej skórze, czym jest zasada narodowosocjalistycznej ideologii „wyniszczenia przez pracę”.

Ponad połowa deportowanych tu osób nie przeżyła obozu, padając ofiarą przemocy, tortur, niedożywienia, niedostatecznej opieki lekarskiej, bezwzględnego wyzysku siły roboczej.

To były mordy dokonywane w różny i sadystyczny sposób. To są niepojęte liczby i niepojęte losy.

Gusen I, II i III były podobozami obozu głównego Mauthausen. Ale samo Gusen I było znacznie większe niż obóz główny. Mauthausen stało się synonimem narodowosocjalistycznej machiny zagłady w Austrii.

Nie mogę zapomnieć opisu konkretnego losu, o którym niedawno czytałem. Jest to dla mnie przykład jeden $\mathrm{z}$ wielu tysięcy:

Jakiś czas temu podczas prac w swoim mieszkaniu w Amsterdamie elektryk znalazł w podwieszanym suficie walizkę zawiniętą w kawałek gazety. W środku były dokumenty i wnioski o wizę do amerykańskich urzędów, złożone 76 lat temu przez prześladowanych ludzi. Elektryk przekazał walizkę Muzeum Żydowskiemu w Amsterdamie, które zbadało kulisy sprawy.

W 1938 roku rodzina Redlich, do której należała walizka, uciekła z Hamburga. Rodzice i ich dwaj synowie, Peter i Günther, udali się do Amsterdamu. Peter został aresztowany w Amsterdamie i w końcu deportowany do Mauthausen. Czytałem, że został zamordowany w Mauthausen, przy czym nie jest jasne, czy nie wydarzyło się to w jednym z podobozów, a więc być może tutaj.

Rodzice zostali deportowani do Westerbork i stamtąd do Auschwitz, gdzie również zostali zamordowani w 1944 roku. Domniemywa się, że także syn Günther został zamordowany w Auschwitz kilka tygodni po rodzicach.

Rodzina została wymazana! Pozostała walizka.

W niej znajdowały się świadectwa szkolne Petera i jego zdjęcie. Na jednym ze świadectw było napisane, że skrupulatnie wypełniał obowiązki szkolne. Są tam też prezenty, które podarował rodzicom w lepszych czasach: ołówek dla matki i zapalniczka dla ojca $^{2}$. W walizce był też list, który Peter napisał z Mauthausen do swoich rodziców: „Czuję się dobrze, nie martwcie się".

2 W artykule opisującym historię walizki jest informacja, że nie znajdowały się w niej wymienione przez prezydenta Van Der Bellena przedmioty, lecz kartka papieru, na której chłopiec notował wydatki, w tym sumy przeznaczone na prezenty dla rodziców. Por. H. Pen, Spectaculaire vondst in een kruipruimte in Zuid: een kistje met het leven van de Joodse, „Het Parool”, 16 kwietnia 2017, https://www.parool.nl/amsterdam/spectaculaire-vondst-in-een-kruipruimte-in-zuid-eenkistje-met-het-leven-van-de-joodse-peter a4487261 (dostęp: 14 marca 2018). 
Wiadomość w walizce informuje o śmierci 19-latka ${ }^{3}$.

W walizce nie ma odpowiedzi na wnioski wizowe rodziny, nie wiemy, czy w ogóle istniała. Peter Redlich to jeden z wielu losów.

Możemy się na tej podstawie domyślać, jakie cierpienie, jakie męki rozniosła maszyneria zagłady nazistów z tego miejsca na całą Europę. Dla mnie pamięć i upamiętnienie grozy systemu narodowosocjalistycznego oznacza ostrzeżenie przed nacjonalizmem, nagonka, egoistycznym wykluczaniem ,innych” i demontowaniem solidarności.

Dziś żyjemy w innej Austrii i innej Europie.

Dziś termin ,prawa człowieka” ma znaczenie, którego w roku 1945 i wcześniej nie miał. Przy wszystkich problemach, z którymi musimy się mierzyć, czasy nie są porównywalne $z$ latami trzydziestymi i czterdziestymi. Porównywalne jest jednak niebezpieczeństwo, że utracimy wrażliwość, empatię da naszych sąsiadów, kolegów z pracy czy szukających pomocy.

W tym sensie uważam upamiętnienie za konieczność obowiązującą w teraźniejszości i sięgającą przyszłości.

Dlatego dziękuję Komitetowi Pamięci Gusen i wszystkim honorowo zaangażowanym członkom za ich niestrudzone działania!

Dziękuję bardzo!

Tłumaczenie: Anna Przybyll

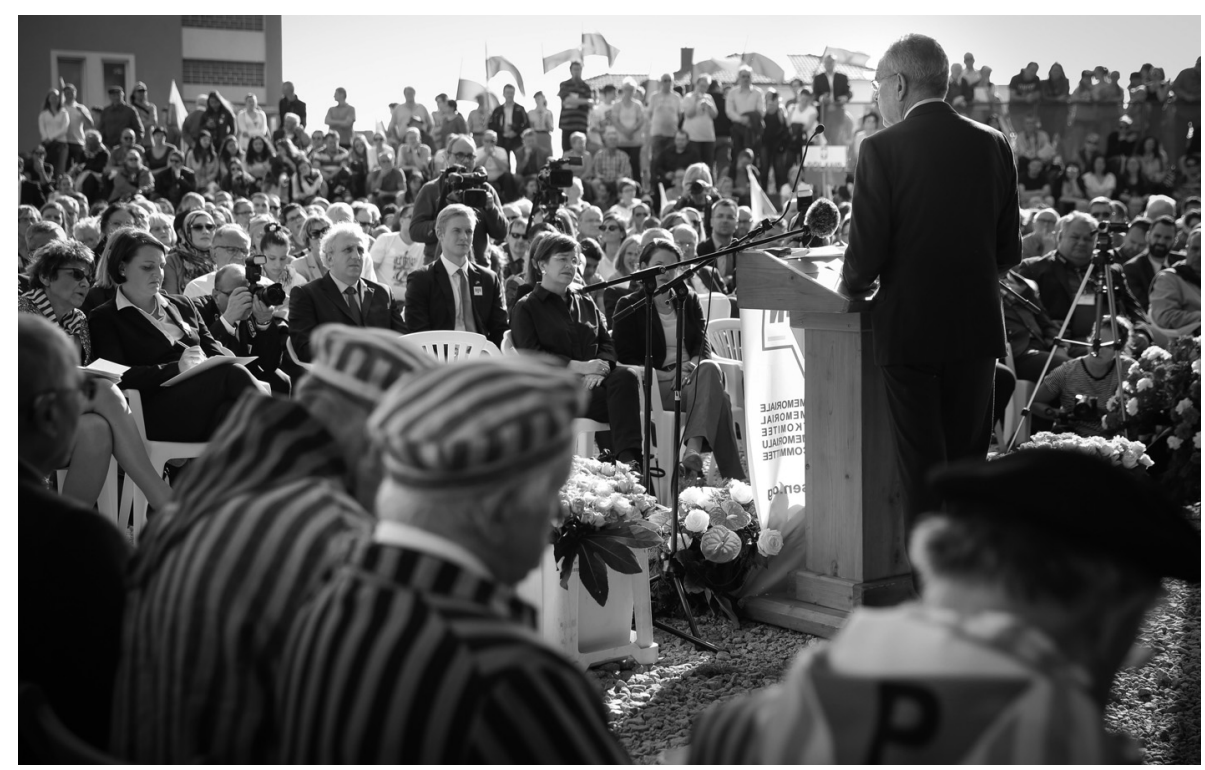

Prezydent Austrii Aleksander Van der Bellen wygłosił przemówienie przy Memoriale KL Gusen z okazji 72. rocznicy wyzwolenia obozu 6 maja 2017 r. Fot.: Peter Lechner/HBF

3 W wyżej wymienionym artykule napisano, że w walizce znaleziono cztery zarejestrowane wnioski rodziny Redlich o emigrację do USA. Najpóźniej datowany formularz jest dowodem na to, iż rodzice wiedzą, że ich syn nie żyje. 


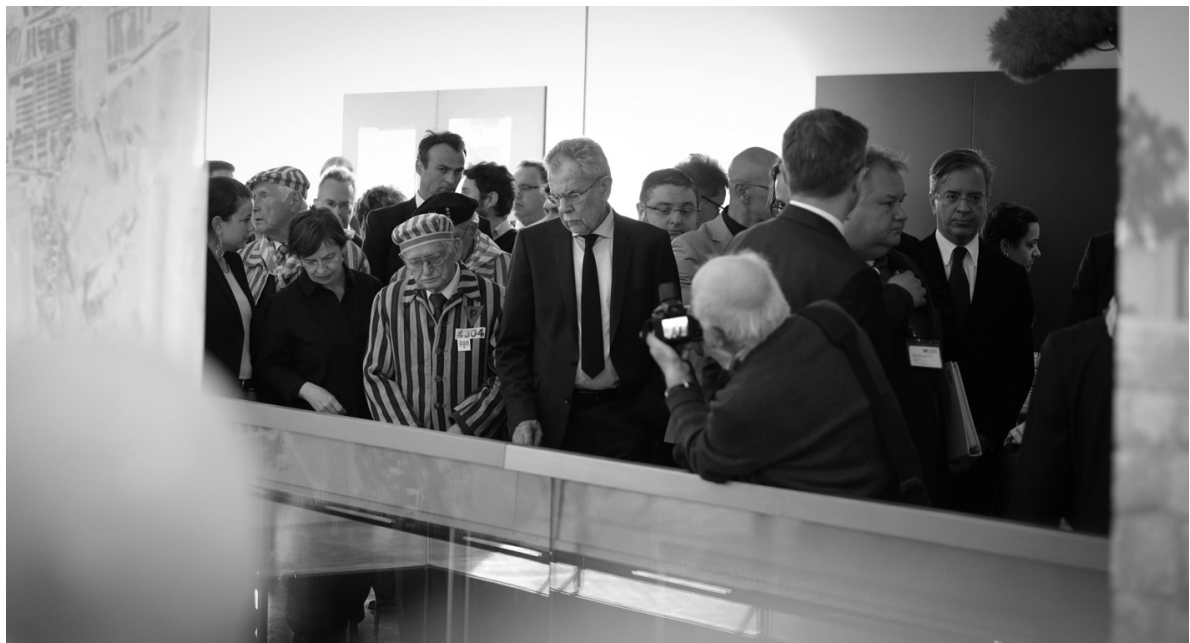

W uroczystościach upamiętniających 72. rocznicę wyzwolenia obozu koncentracyjnego Gusen po raz pierwszy w historii uczestniczył prezydent Austrii. Fot.: Peter Lechner/HBF

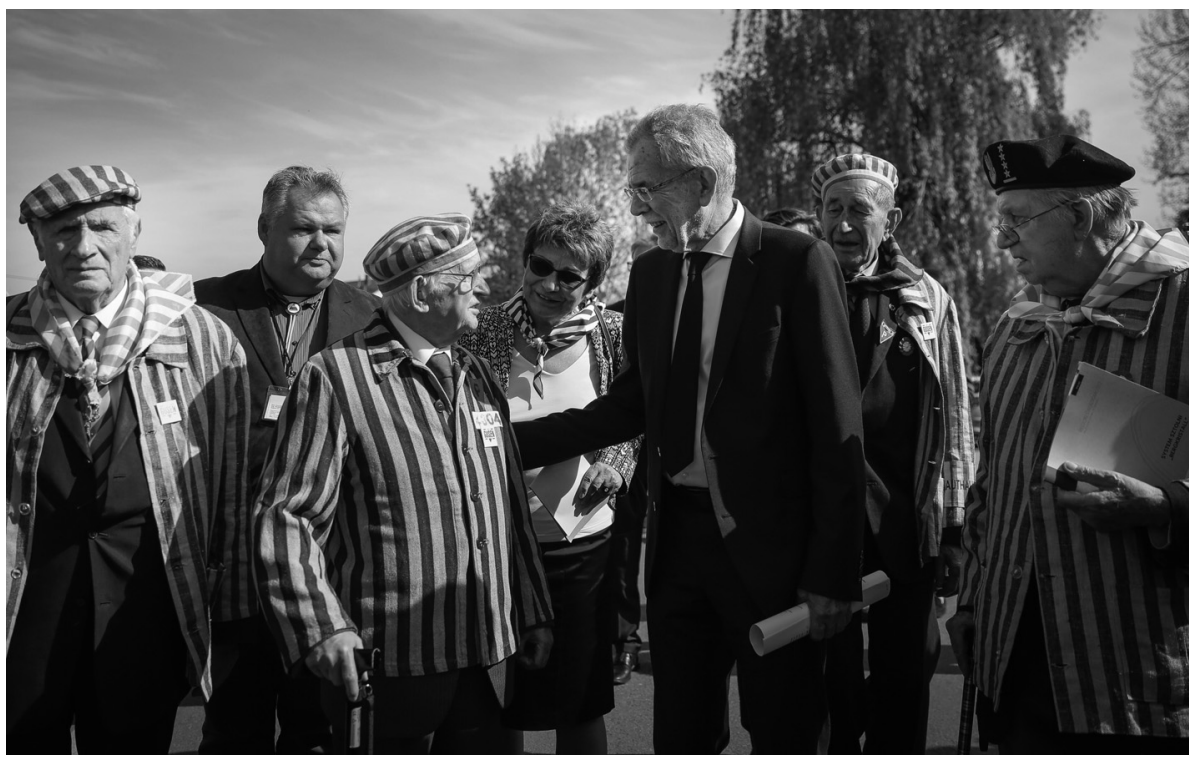

Prezydent Austrii Aleksander Van der Bellen spotkał się z byłymi więźniami obozu koncentracyjnego Gusen w 72. rocznicę wyzwolenia obozu 6 maja 2017 roku Fot.: Peter Lechner/HBF 